\title{
Health-related quality of life and depressive symptoms in undergraduate nursing students
}

\author{
Ismelinda Maria Diniz Mendes Souza ${ }^{1}$ \\ Helena Borges Martins da Silva Paro \\ Rogerio Rizo Morales ${ }^{3}$ \\ Rogerio de Melo Costa Pinto ${ }^{4}$ \\ Carlos Henrique Martins da Silva ${ }^{5}$
}

\begin{abstract}
This is a descriptive, cross-sectional study aimed at investigating the health-related quality of life (HRQoL) of nursing students and its relationship with year of training, sociodemographic variables and the intensity of depressive symptoms. A convenience sample of 256 students, out of 353 eligible (72\%), responded to the Medical Outcomes Study - The 36 Item ShortForm Health Survey (SF-36) and the Beck Depression Inventory (BDI) (self-administered). Final-year students, females and students with a higher intensity of depressive symptoms presented lower SF-36 scores in the physical functioning, vitality and social functioning domains. Institutional psychopedagogic support programs may minimize this negative impact on the HRQOL and encourage better professional performance of students in higher vulnerability situations.
\end{abstract}

Descriptors: Education, Nursing; Students, Nursing; Quality of Life; Depression.

\footnotetext{
${ }_{1}^{1}$ MSc, Professor, Universidade Presidente Antonio Carlos, Brazil.

2 MSc, Assistant Professor, Faculdade de Medicina, Universidade Federal de Uberlândia, Brazil.

${ }^{3}$ Physician, MSc, Hospital das Clínicas, Universidade Federal de Uberlândia, Brazil.

${ }^{4}$ PhD, Adjunct Professor, Faculdade de Matemática, Universidade Federal de Uberlândia, Brazil.

${ }^{5} \mathrm{PhD}$, Associate Professor, Faculdade de Medicina, Universidade Federal de Uberlândia, Brazil.
} 


\title{
Qualidade de vida relacionada à saúde e sintomas depressivos de estudantes do curso de graduação em Enfermagem
}

Trata-se de estudo descritivo e transversal, que investigou a qualidade de vida relacionada à saúde (QVRS) de estudantes de Enfermagem e a relação da QVRS com o ano de estudo, as variáveis sociodemográficas e a intensidade de sintomas depressivos. Uma amostra acidental de 256 estudantes dos 353 elegíveis (72\%) respondeu ao Medical Outcomes Study - The 36 Item Short-Form Health Survey (SF-36) e ao Inventário de Depressão de Beck (IDB). Estudantes do último ano do curso, sobretudo do sexo feminino e com maior intensidade de sintomas depressivos, apresentaram menores escores do SF-36 nos domínios capacidade funcional, vitalidade e aspectos sociais. O prejuízo na QVRS ocorre sobretudo no último ano do curso, nos estudantes do sexo feminino ou com sintomas depressivos. Programas institucionais de aconselhamento psicopedagógico poderiam minimizar o impacto negativo detectado na QVRS e contribuir para melhor formação e desempenho profissional dos estudantes em situação de maior vulnerabilidade.

Descritores: Educação em Enfermagem; Estudantes de Enfermagem; Qualidade de Vida; Depressão.

\section{Calidad de vida relacionada a la salud y síntomas depresivos de estudiantes del curso de graduación en enfermería.}

\begin{abstract}
Se trata de un estudio descriptivo y transversal que investigó la calidad de vida relacionada a la salud (CVRS) de los estudiantes de enfermería y la relación con años de estudio, las variables sociodemográficas y la intensidad de los síntomas depresivos. Una muestra accidental de 256 estudiantes de 353 elegibles (72\%) respondió el Medical Outcomes Study - The 36 Item Short-Form Health Survey (SF-36) y el Inventario de Depresión de Beck (IDB) (auto-aplicación). Estudiantes del último año del curso, los del sexo femenino y con mayor intensidad de síntomas depresivos, presentaron menores puntuaciones del SF-36 en los dominios capacidad funcional, vitalidad y aspectos sociales. El impacto es mayor en el último año del curso, los estudiantes de sexo femenino o con síntomas depresivos. Programas de apoyo psicológico podrían minimizar este impacto y contribuir a una mejor formación y desempeño profesional de los estudiantes en situación de mayor vulnerabilidad.
\end{abstract}

Descriptores: Educación en Enfermería; Estudiantes de Enfermería; Calidad de Vida; Depresión.

\section{Introduction}

The curricular guidelines of the undergraduate program in Nursing in Brazil propose a generalist, humanistic, critical and reflective formation, based on scientific and intellectual rigor, guided by ethical principles $^{(1)}$. Although some institutions seek to construct a professional profile that meets the requirements of these guidelines, their implementation is still weak and faces some challenges(2). Improvements in academic and professional performance will depend on the comprehension of the psycho-emotional changes of the student originating from the graduation and the valorization of aspects that seem to affect their quality of life $\mathrm{e}^{(3)}$.

Quality of life is defined by the World Health Organization (WHO) as "the individual's perception of their position in life considering the cultural context and value system in which they live and in relation to their goals, expectations, standards, concerns and desires". It is a broad, subjective and multidimensional concept ${ }^{(4)}$ that approaches the holistic concept of health as "a state 
of complete physical, mental and social well-being, and not merely the absence of disease or infirmity"(5). The term health related quality of life (HRQoL) refers to the influence of the health status on this perception of wellbeing ${ }^{(6)}$.

Although the educational institutions recognize the importance of considering the well-being and health of the students as a strategy for improving the quality of the education, the few studies that deal with the evaluation of QoL of nursing students suggest a negative impact on the $\mathrm{QoL}^{(3,7-8)}$, especially in the first years of the course(3). However, there are no studies on the HRQoL of these students, on the possible differences in the magnitude of the compromise in the various health dimensions, or its relationship with the presence of depressive symptoms. Knowledge of the self-perceived HRQoL of nursing students may assist in directing strategies for the students in risk situations, and collaborate in the implementation of the national curriculum guidelines and in the formation of professionals that meet the requirements of the market.

The aim of this study was to evaluate the HRQoL of students during the Nursing graduation and possible relationships between the socio-demographic variables and the intensity of depressive symptoms, according to year of training and socio-demographic variables.

\section{Methods}

This is a descriptive, cross-sectional study conducted between June and July 2007, approved by the Research Ethics Committee of the educational institution of the study, a public federal university of Minas Gerais (Protocol No. 208/07). Students from first to fourth year of the Nursing graduation, registered in the first semester of 2007 and present in class at the application of the questionnaires, were invited to participate in the study.

During the period of data collection, the Nursing graduation at this university offered 40 places per semester through the public selection process (vestibular). The graduation course lasted four years and was developed mainly during the evening. In the first two years, basic disciplines were predominantly taught, then professional practice was developed during the day and in the fourth year, preparation of the thesis was introduced. Prior contact was made with the director of the course and later with the professors responsible for the disciplines for scheduling data collection. The students were approached in the classroom or at the internship site. Before distributing the instruments the students were informed of the research objectives and the importance of their collaboration was stressed. After agreeing and signing the Terms of Informed Consent, the students answered the SF-36, the BDI and a questionnaire by self-administration to identify the sociodemographic characteristics of the subjects.

The Brazilian version of the SF-36(9) is a generic instrument for evaluating $\mathrm{HRQOL}$, which contains 36 items divided between eight domains (physical functioning, general health perceptions, bodily pain, role limitations caused by physical problems, mental health, vitality, social functioning, and role limitations caused by emotional problems), with two summary components (physical and mental). The scores of the scales are transformed into values from 0 (worst possible HRQoL) to 100 (best possible HRQoL ${ }^{(10)}$. The Beck Depression Inventory (BDI) is a self-evaluation scale of depressive symptoms ${ }^{(11)}$, translated and validated into Portuguese and used among clinical and nonclinical populations(12). It consists of 21 items that assess the intensity of depressive symptoms. Each item has four alternatives, with scores ranging from 0 (lowest intensity) to 3 (highest intensity). The cutoff point of 15 has been used to identify the depressive syndrome ${ }^{(13)}$ in nursing students ${ }^{(14)}$. This scale was used to determine the intensity of depressive symptoms and to compare the HRQOL according to this intensity among nursing students.

\section{Data Analysis}

The internal consistency reliability was assessed using Cronbach's alpha coefficient. Coefficients higher than 0.7 were considered adequate(15). Descriptive statistics were used to characterize the study participants, regarding the socio-demographics, the determination of the SF-36 and the BDI scores. The SF-36 summary scores (physical and mental) were calculated from the normative values of the North American population using the software supplied with the license to use the questionnaire. Since the data presented non-normal distribution (D'Agostino's test), nonparametric tests were used to compare the scores of the BDI and the SF-36 according to year of training (Kruskal-Wallis analysis of variance by ranks), socio-demographic variables (Asymptotic Multiple Comparisons of Binomial Proportions test) and intensity of depressive symptoms (Mann-Whitney test). The SF-36 scores were also correlated with family income (Spearman's correlation coefficient). The level of significance adopted was $\leq 0.05$. The effect size (ES) was calculated (the ratio between 
the median differences and the interquartile range), to determine the magnitude of the differences between the statistically different groups in the comparison of HRQOL scores according to the BDI and gender.

\section{Results}

The Cronbach's coefficient alpha of the SF-36 domains ranged from 0.7 to 0.8 . Of the 353 students enrolled, $256(72.5 \%)$ participated in the study. The mean age was 21.5 years $(S D=2.9)$. The majority were female $(80.5 \%)$, single $(89.8 \%)$, childless $(94.5 \%)$ and presented a low frequency of depressive symptoms according to the BDI (85.9\%). The BDI scores did not differ according to year of training (Table 1 ).

Table 1 - Characteristics of the undergraduate students of the Nursing school, 2007. Federal University of Uberlândia, Uberlândia, MG, Brazil

\begin{tabular}{|c|c|c|c|c|}
\hline Variable / period & $\begin{array}{c}1^{\text {st }} \text { year } \\
\text { n }(\%)\end{array}$ & $\begin{array}{c}2^{\text {nd }} \text { year } \\
n(\%)\end{array}$ & $\begin{array}{c}3^{\text {rd }} \text { year } \\
\text { n }(\%)\end{array}$ & $\begin{array}{c}4^{\text {th }} \text { year } \\
\text { n }(\%)\end{array}$ \\
\hline $\begin{array}{l}\text { Age } \\
\text { Mean (SD) }\end{array}$ & $19.1(2.0)$ & $20.8(2.4)$ & $22.3(2.7)$ & $23.6(2.8)$ \\
\hline Male gender* & $13 / 58(22.4)$ & $9 / 63(14.3)$ & $17 / 71(24.0)$ & $11 / 64(17.2)$ \\
\hline Marital status married* & $3 / 58(5.1)$ & $6 / 63(9.6)$ & $11 / 71(15.5)$ & $5 / 64(7.8)$ \\
\hline Children* & $1 / 58(1.7)$ & $2 / 63(3.2)$ & $6 / 71(8.5)$ & $5 / 64(7.8)$ \\
\hline Employment* & $7 / 58(12.0)$ & $19 / 63(30.2)$ & $11 / 71(15.5)$ & $9 / 64(14.1)$ \\
\hline Chronic disease mentioned* & $18 / 58(31.0)$ & $19 / 63(30.2)$ & $15 / 71(21.1)$ & $11 / 64(17.2)$ \\
\hline Not living with family members* & $16 / 57(28.0)$ & $17 / 63(26.9)$ & $17 / 69(24.6)$ & $10 / 62(16.1)$ \\
\hline Family income $<5 \mathrm{MW}^{*}$ & $17 / 40(42.5)$ & $26 / 56(46.4)$ & $19 / 47(40.5)$ & $20 / 54(37.1)$ \\
\hline $\begin{array}{l}\text { BDI, median }{ }^{\dagger} \\
(\text { P25 - P75) }\end{array}$ & $7.0(5.0-11.0)$ & $7.0(4.5-13.0)$ & $7.0(4.0-12.5)$ & $9.0(6.0-13.0)$ \\
\hline $\begin{array}{l}\text { BDI scores* } \\
>15(\%)\end{array}$ & $4 / 58(6.8)$ & $9 / 63(14.3)$ & $10 / 71(14.0)$ & $13 / 64(20.3)$ \\
\hline
\end{tabular}

MW: minimum wages; BDI: Beck Depression Inventory

* Asymptotic Multiple Comparisons of Binomial Proportions test ( $p$-value $>0.05$ )

${ }^{+}$Kruskal-Wallis test ( $p$-value $\left.>0.05\right)$;

\section{HRQoL according to the year of study}

Comparing the SF-36 scores of nursing students in different years of training, statistically significant differences were found in the physical functioning, vitality and social functioning domains. In the physical functioning domain, fourth-year students presented lower scores than those of the first year $(p=0.03$,
$E S=0.5)$. In the vitality domain, fourth-year students presented scores significantly lower when compared with the scores of those of the first and second years $(p=0.00, E S=0.5$ and 0.6 , respectively). In the social functioning domain, the fourth-year group obtained significantly lower scores than the students from all the other years of training (Table 2).

Table 2 - SF-36 scores of the students in the undergraduate nursing school according to the year of study, 2007. Federal University of Uberlândia, Uberlândia, MG, Brazil

\begin{tabular}{|c|c|c|c|c|c|}
\hline \multirow{2}{*}{$\begin{array}{c}\text { Domains and } \\
\text { Components } \\
\text { SF-36 }\end{array}$} & \multicolumn{4}{|c|}{$\begin{array}{c}\text { Median } \\
\text { (25-75 percentile) }\end{array}$} & \multirow{2}{*}{$P$ value * } \\
\hline & $\begin{array}{l}1^{\text {st }} \text { year } \\
(n=58)\end{array}$ & $\begin{array}{l}2^{\text {nd }} \text { year } \\
(n=63)\end{array}$ & $\begin{array}{l}3^{\text {rd }} \text { year } \\
(n=71)\end{array}$ & $\begin{array}{l}4^{\text {th }} \text { year } \\
(n=64)\end{array}$ & \\
\hline Physical Functioning & $\begin{array}{c}95^{\mathrm{a}} \\
(90-100)\end{array}$ & $\begin{array}{c}95^{\mathrm{ab}} \\
(85-100)\end{array}$ & $\begin{array}{c}95^{\mathrm{ab}} \\
(85-95)\end{array}$ & $\begin{array}{c}90^{\mathrm{b}} \\
(80-95)\end{array}$ & 0.03 \\
\hline $\begin{array}{l}\text { Role limitations caused by } \\
\text { physical problems }\end{array}$ & $\begin{array}{c}75 \\
(50-100)\end{array}$ & $\begin{array}{c}75 \\
(50-100)\end{array}$ & $\begin{array}{c}75 \\
(50-100)\end{array}$ & $\begin{array}{c}75 \\
(25-100)\end{array}$ & 0.65 \\
\hline Bodily Pain & $\begin{array}{c}63 \\
(53-84)\end{array}$ & $\begin{array}{c}62 \\
(51-84)\end{array}$ & $\begin{array}{c}62 \\
(52-84)\end{array}$ & $\begin{array}{c}56.5 \\
(41-84)\end{array}$ & 0.09 \\
\hline General Health Perceptions & $\begin{array}{c}72 \\
(57-87)\end{array}$ & $\begin{array}{c}80 \\
(64.5-87)\end{array}$ & $\begin{array}{c}77 \\
(67-87)\end{array}$ & $\begin{array}{c}77 \\
(57-90.5)\end{array}$ & 0.94 \\
\hline Vitality & $\begin{array}{c}57.5^{a} \\
(40-75)\end{array}$ & $\begin{array}{c}55^{\mathrm{a}} \\
(40-65)\end{array}$ & $\begin{array}{c}50^{a b} \\
(35-67.5)\end{array}$ & $\begin{array}{c}40^{\mathrm{b}} \\
(25-55)\end{array}$ & 0.00 \\
\hline
\end{tabular}


Table 2 - (continuation)

\begin{tabular}{|c|c|c|c|c|c|}
\hline \multirow{2}{*}{$\begin{array}{l}\text { Domains and } \\
\text { Components } \\
\text { SF-36 }\end{array}$} & \multicolumn{4}{|c|}{$\begin{array}{c}\text { Median } \\
\text { (25-75 percentile) }\end{array}$} & \multirow{2}{*}{$P$ value * } \\
\hline & $\begin{array}{l}1^{\text {st }} \text { year } \\
(\mathrm{n}=58)\end{array}$ & $\begin{array}{l}2^{\text {nd }} \text { year } \\
(\mathrm{n}=63)\end{array}$ & $\begin{array}{l}3^{\text {rd }} \text { year } \\
(n=71)\end{array}$ & $\begin{array}{l}4^{\text {th }} \text { year } \\
(\mathrm{n}=64)\end{array}$ & \\
\hline Social Functioning & $\begin{array}{c}75^{a} \\
(50-87)\end{array}$ & $\begin{array}{c}62.5^{\mathrm{a}} \\
(50-87)\end{array}$ & $\begin{array}{c}75.0^{\mathrm{a}} \\
(50-87)\end{array}$ & $\begin{array}{c}50^{\mathrm{b}} \\
(37-75)\end{array}$ & 0.00 \\
\hline $\begin{array}{l}\text { Role limitations caused by } \\
\text { emotional problems }\end{array}$ & $\begin{array}{c}66 \\
(33-100)\end{array}$ & $\begin{array}{c}33.3 \\
(0-66.7)\end{array}$ & $\begin{array}{c}33.3 \\
(0-100)\end{array}$ & $\begin{array}{c}33.3 \\
(33-75)\end{array}$ & 0.66 \\
\hline Mental Health & $\begin{array}{c}64 \\
(53-80)\end{array}$ & $\begin{array}{c}60 \\
(46-80)\end{array}$ & $\begin{array}{c}64 \\
(48-74)\end{array}$ & $\begin{array}{c}56 \\
(47-72)\end{array}$ & 0.24 \\
\hline Physical Component Summary & $\begin{array}{c}52 \\
(49-56.8)\end{array}$ & $\begin{array}{c}53 \\
(49-56.5)\end{array}$ & $\begin{array}{c}52.3 \\
(46.3-55.7)\end{array}$ & $\begin{array}{c}52.5 \\
(45-56.1)\end{array}$ & 0.80 \\
\hline Mental Component Summary & $\begin{array}{c}39 \\
(33.6-49.8)\end{array}$ & $\begin{array}{c}39 \\
(30-48.8)\end{array}$ & $\begin{array}{c}39 \\
(29-50.2)\end{array}$ & $\begin{array}{c}36.3 \\
(28.1-43)\end{array}$ & 0.08 \\
\hline
\end{tabular}

* Kruskal-Wallis test, medians followed by the same letter are not statistically different to each other according to Dunn's test.

HRQoL and clinical and sociodemographic variables

The SF-36 scores of the nursing students did not differ according to their employment status ( $p>0.05$ ). There was no statistically significant correlation between family income and the majority of the domains and components of the SF-36, except for the role limitations caused by emotional problems domain $(r=-0.15, p=$ 0.03) (data not shown). The students that presented a higher intensity of depressive symptoms obtained scores significantly lower in all the domains and in the summary components of the SF-36 (Table 3). Female students had significantly lower scores than male students in the physical functioning, bodily pain, vitality, social functioning, role limitations caused by emotional problems, mental health domains and in the mental component summary $(p<0.05)$ (Table 3$)$.

Table 3 - SF-36 scores of the students of the undergraduate nursing school according to the BDI score and gender, 2007. Federal University of Uberlândia, Uberlândia, MG, Brazil

\begin{tabular}{|c|c|c|c|c|c|c|c|c|}
\hline $\begin{array}{c}\text { Domains/ } \\
\text { Components }\end{array}$ & $\begin{array}{c}\mathrm{BDI} \leq 15 \\
\mathrm{n}=\mathbf{2 2 0}\end{array}$ & $\begin{array}{c}\text { BDI > } 15 \\
n=36\end{array}$ & ES & p * & $\begin{array}{c}\text { Female } \\
\mathrm{n}=174\end{array}$ & $\begin{array}{l}\text { Male } \\
n=45\end{array}$ & ES & $p^{*}$ \\
\hline Physical Functioning & $\begin{array}{c}95 \\
(85-100)\end{array}$ & $\begin{array}{c}85 \\
(75-95)\end{array}$ & 0.6 & 0.00 & $\begin{array}{c}90 \\
(85-95)\end{array}$ & $\begin{array}{c}95 \\
(90-100)\end{array}$ & 0.5 & 0.00 \\
\hline Role limitations caused by physical problems & $\begin{array}{c}75 \\
(50-100)\end{array}$ & $\begin{array}{c}50 \\
(25-81.2)\end{array}$ & 0.5 & 0.00 & $\begin{array}{c}75 \\
(50-100)\end{array}$ & $\begin{array}{c}100 \\
(50-100)\end{array}$ & 0.5 & 0.24 \\
\hline Bodily Pain & $\begin{array}{c}64 \\
(51-84)\end{array}$ & $\begin{array}{c}51 \\
(41-62)\end{array}$ & 0.7 & 0.00 & $\begin{array}{c}62 \\
(51-74)\end{array}$ & $\begin{array}{c}74 \\
(52-84)\end{array}$ & 0.5 & 0.00 \\
\hline General Health Perceptions & $\begin{array}{c}82 \\
(67-90)\end{array}$ & $\begin{array}{c}52 \\
(42-63.2)\end{array}$ & 1.3 & 0.00 & $\begin{array}{c}77 \\
(62-87)\end{array}$ & $\begin{array}{c}77 \\
(67-85)\end{array}$ & 0.0 & 0.99 \\
\hline Vitality & $\begin{array}{c}55 \\
(40-70)\end{array}$ & $\begin{array}{c}30 \\
(20-35)\end{array}$ & 0.8 & 0.00 & $\begin{array}{c}45 \\
(30-60)\end{array}$ & $\begin{array}{c}65 \\
(40-75)\end{array}$ & 0.6 & 0.00 \\
\hline Social Functioning & $\begin{array}{c}75 \\
(50-87)\end{array}$ & $\begin{array}{c}37.5 \\
(25-53.1)\end{array}$ & 1.0 & 0.00 & $\begin{array}{c}62.5 \\
(37.5-75)\end{array}$ & $\begin{array}{c}75 \\
(50-87.5)\end{array}$ & 0.3 & 0.00 \\
\hline Role limitations caused by emotional problems & $\begin{array}{c}66 \\
(33-100)\end{array}$ & $\begin{array}{c}0 \\
(0-33.3)\end{array}$ & 0.9 & 0.00 & $\begin{array}{c}33.3 \\
(0-66.7)\end{array}$ & $\begin{array}{c}66.7 \\
(33.3-100)\end{array}$ & 0.5 & 0.02 \\
\hline Mental Health & $\begin{array}{c}68 \\
(52-80)\end{array}$ & $\begin{array}{c}36 \\
(32-48)\end{array}$ & 1.1 & 0.00 & $\begin{array}{c}60 \\
(44-72)\end{array}$ & $\begin{array}{c}72 \\
(52-80)\end{array}$ & 0.4 & 0.01 \\
\hline Physical Component Summary & $\begin{array}{c}53.5 \\
(48.7-57)\end{array}$ & $\begin{array}{c}47.5 \\
(43.3-52.5)\end{array}$ & 0.7 & 0.00 & $\begin{array}{c}52.6 \\
(45.7-56.8)\end{array}$ & $\begin{array}{c}53.2 \\
(49.1-56.2)\end{array}$ & 0.0 & 0.34 \\
\hline Mental Component Summary & $\begin{array}{c}41 \\
(33-49.8)\end{array}$ & $\begin{array}{c}27.1 \\
(19.5-30.2)\end{array}$ & 0.8 & 0.00 & $\begin{array}{c}37.1 \\
(29.4-45.2)\end{array}$ & $\begin{array}{c}47.2 \\
(32.5-53.3)\end{array}$ & 0.6 & 0.00 \\
\hline
\end{tabular}

* Mann-Whitney test

\section{Discussion}

The results of this study indicate multidimensional impairment in the HRQoL of nursing students as previously described in studies that addressed the QoL of this population ${ }^{(3,7-8)}$. Furthermore, it was noted that a negative impact in the perception of well-being was greater in students of the final year of training (fourth year) compared to students from other years, in females and in those with a greater intensity of depressive symptoms. 
The trajectories of nursing students are similar in different schools. In the first year, students go through changes and new experiences resulting from their joining the university and have to adjust to the school(16). During this phase, they develop predominantly theoretical and practical activities in the classroom and laboratories(3). In the second year, the nursing student enters the hospital environment to carry out practical activities linked directly to the patient, a situation that generates anxiety, fear, anguish, conflict, stress and depressive symptoms ${ }^{(3,16-17)}$. Conflicts generated in relationships with other healthcare professionals, professors and employees of the sector, the dichotomy between theory and practice ${ }^{(8)}$, and an overload of theoretical and practical activities ${ }^{(18)}$ are situations experienced by these students. In the third year, theoretical and practical activities are continued and in general students are more adapted to the university environment and the teaching and learning scenarios ${ }^{(3)}$. In the fourth year of training, the addition of the thesis to the academic assignments, expectations regarding the graduation, feelings of inadequacy, and insecurity about the future and entering the labor market can justify the impairment in the HRQoL of students of this period, predominantly observed in the physical functioning, vitality and social functioning domains. Therefore, unlike the findings of other researchers ${ }^{(3)}$, the greatest negative impact in the HRQoL was observed in the students of the final year of training. This result seems plausible as, at the end of the course, conflictual relationships experienced by students in the hospital environment are emphasized, justified by the hegemonic view of medicine that places the physician as the central character and the other healthcare professionals as complementary. The reproduction of these conflicts takes place internally in the nursing team, with the incorporation of the professional nurse as dominant and the other professional categories as subaltern.

Female students presented more impairment in the domains related to limitations of the quotidian physical activities (physical functioning), energy (vitality) and bodily pain, which may be connected to physical characteristics inherent to the female gender, associated with a burden due to an overload of traditionally female activities and greater emotional sensitivity (role limitations caused by emotional problems, mental health and the mental component). Similar results were found in a study that evaluated the HRQoL of medical students in Brazil(19).
In the present study, a negative correlation was found, although very low, between the monthly family income and the role limitations caused by emotional problems domain. This result allows the inference that, perhaps surprisingly, the students with low incomes presented less compromise in their mental health. A similar result was previously observed(3). However, other studies indicate that people with low incomes present worse QoL and impairment in the mental health, physical health and physical functioning indicators ${ }^{(20)}$.

The results of the present study indicate that the intensity of depressive symptoms increases throughout the graduation training, is higher in the final year, and that there is a correlation between moderate intensity depressive symptoms and negative impact in the HRQoL. Students with mood disorder present average levels of self-esteem ${ }^{(14)}$. The depressive state can produce feelings of sadness, loss of interest in normal situations, lack of pleasure, emotional instability, and changes in appetite, sleep, and rest, among other aspects. In this study, the nursing students were predominantly young, single, childless and economically stable. The presence of depressive symptoms, especially in the students of the final year of the nursing training, who are about to enter the competitive and unstable labor market, may hinder the development of academic and personal activities and, consequently, the future professional.

Some measures can minimize the impairment in the HRQoL of nursing students. In addition to knowing the sources of problems during the teaching-learning process and offering multi-disciplinary support for the adaptation of the student, educational managers should: encourage the creation of tutorial programs directed towards improvements in pedagogic programs and in student-professor relationships(21); perform and encourage seminars that develop skills, self-control and relaxation in situations that cause anxiety, in order to explore the capacities of the students and to train them in public speaking(22); provide interventions to reduce individual and organizational stress through healthier behavior, improved lifestyle, self-esteem ${ }^{(23)}$ and mental health(24).

Some methodological limitations of this study should be considered. Despite the use of a generic instrument allowing a multidimensional evaluation of the HRQoL and the comparison between students of different years of training, it is possible that the questionnaire was not able to detect differences related to specific conditions of these students. However, the instrument was found to be adequate and reliable for demonstrating the many 
aspects of the HRQoL of the students. Further studies that aim to evaluate the particularities of this population should use specific HRQoL instruments. Another methodological issue concerns the cross-sectional design of the study, which did not allow an investigation of the risk factors for the impaired HRQoL found among the students.

\section{Conclusions}

Students of the undergraduate nursing school presented impairment in their HRQoL, especially the final-year students, the females, and those with depressive symptoms. Further studies are suggested to investigate the possible contribution of active teachinglearning methodologies and continuous psychopedagogic support, aiming for a better formation and the improved professional performance of those students in risk situations.

\section{References}

1. Ministério da Educação (BR). Diretrizes Curriculares Nacionais dos Cursos de Graduação em Enfermagem, Medicina e Nutrição. Brasília: Ministério da Educação; 2001. [acesso 1 out 2006]. Disponível em http://portal. mec.gov.br/dmdocuments/ces1133.pdf

2. Silva KL, Sena RR. [Nursing education: building up the integrality of care]. Rev. Latino-Am. Enfermagem. set-out 2006;14(5):755-61.

3. Kawakame PMG, Miydahira AMK. Qualidade de vida de estudantes de graduação em enfermagem. Rev Esc Enferm USP. 2005;2(39):164-72.

4. The WHOQOL Group. The world health organization quality of life assessment (WHOQOL): position paper from the world health organization. Soc Sci Med. 1995;41(10): 1403-9.

5. World Health Organization. Preamble to the Constitution of the World Health Organization. Official Records. Bull WHO. 1946;2:100.

6. Ebrahim S. Clinical and Public Health Perspectives and Applications of Health-Related Quality of Life Measurement. Soc Sci Med. 1995;41(10):1383-94.

7. Saupe R, Nietche EA, Cestari ME, Giorgi MDM, Krahl M. [Quality of life of nursing students]. Rev. Latino-Am. Enfermagem. jul-ago 2004;12(4):636-42.

8. Oliveira RA, Ciampone MHT. [Nursing students' life quality: building a process and interventions]. Rev Esc Enferm USP. 2008;42(1):57-65.

9. Ciconelli RM, Ferraz MB, Santos W, Meinão I, Quaresma MR. Tradução para a língua portuguesa e validação do questionário genérico de avaliação de qualidade de vida SF-36 (Brasil SF-36). Rev Bras Reumatol. 1999;39(3):143-50.

10. Ware JE, Sherbourne CD. The MOS 36-Item ShortForm Health Survey (SF-36). I. Conceptual Framework and Item Selection. Med Care. 1992;30(6):473-81.

11. Beck AT, Ward CH, Mendelson M, Mock J, Erbaugh J. An inventory for measuring depression. Arch Gen Psychiatry. 1961;4:561-71.

12. Gorenstein C, Andrade L. Validation of a Portuguese version of the Beck Depression Inventory and the SateTrait Anxiety Inventory in Brazilian subjects. Braz J Med Biol Res. 1996;29(4):453-7.

13. Kendall PC, Hollon SD, Beck AT, Hammen CI, Ingram RE. Issues and Recommendations Regarding use of the Beck Depression Inventory. Cognit Ther Res. 1987;11(3):289-99.

14. Furegato ARF, Santos JLF, Silva EC. [Depression among nursing students associated to their self-esteem, health perception and interest in mental health]. Rev. Latino-Am. Enfermagem. mar-abr 2008;16(2):198-204. 15. Scientific Advisory Committee of the Medical Outcomes Trust. Assessing health status and quality-oflife instruments: Attributes and review criteria. Qual Life Res. 2002;11:193-205.

16. Scherer ZAP, Scherer EA, Carvalho AMP. [Reflections on nursing teaching and students' first contact with the profession]. Rev. Latino-Am. Enfermagem. mar-abr 2006;14(2):285-91.

17. Garro IMB, Camillo SO, Nóbrega MPSS. Depressão em graduandos de enfermagem. Acta Paul Enferm. 2006;19(2):162-7.

18. Timmins $F$, Kaliszer $M$. Aspects of nurse education programmes that frequently cause stress to nursing students - fact-finding sample survey. Nurse Educ Today. 2002;22:203-11.

19. Paro HBMS, Morales NMO, Silva CHM, Rezende CHA, Pinto RMC, Morales RR, et al. Health-related quality of life of medical students. Med Educ. 2010;44:227-35.

20. Jiang $Y$, Hesser JL. Associations between healthrelated quality of life and demographics and health risks. Results from Rhode Island's 2002 behavioral risk factor survey. Health Qual Life Outocomes [periódico na Internet]. 2006. [acesso 15 jan 2007];4:14. Disponível em: http://www.hqlo.com/content/4/1/14.

21. Saupe R, Geib LTC. [Tutorial programs for nursing courses]. Rev. Latino-Am. Enfermagem. set-out 2002;10(5):721-6.

22. Montes-Berges B, Augusto M. Exploring the relationship between perceived emotional intelligence, coping, social 
support and mental health in nursing students. J Psychiatry Ment Health Nurs. 2007;14:163-71.

23. Jones MC, Johonston M A. Reducing distress in first level and student nurses: a review of the applied stress management literature. J Adv Nurs. 2000;32(1):66-74.

24. Figueiredo RM, Oliveira, MAP. [Need of university students for a mental health orientation and education service]. Rev. Latino-Am. Enfermagem. jan 1995;3(1):5-18. 